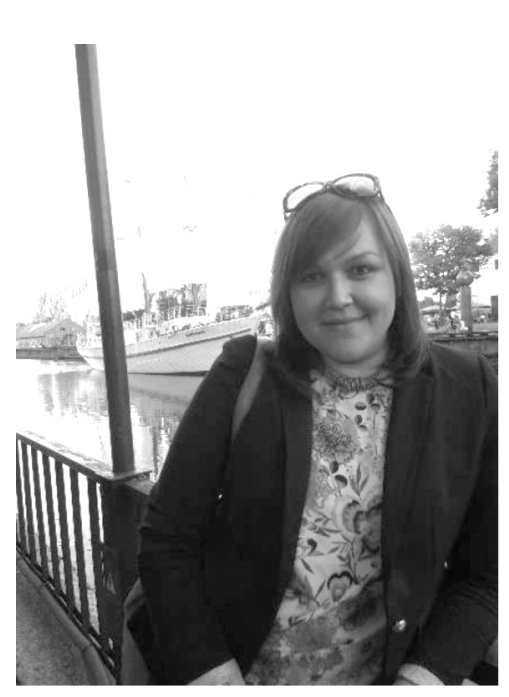

Kristina Block ytè-Naujokè - humanitarinių mokslų daktaré, Klaipèdos universiteto Socialinių ir humanitarinių mokslų fakulteto Filologijos katedros mokslo darbuotoja

Moksliniai interesai: etnologija, folkloras, etninẻ kultūra, papročiai, šventès

El.paštas: kristina.blockyte@gmail.com

Kristina Blockyte்-Naujoke - doctor of humanities (ethnology), researcher at the Klaipeda University, Faculty of Social Sciences and Humanities, Department of Philology

Research interests: ethnology, folklore, ethnical culture, customs, holidays

E-mail: kristina.blockyte@gmail.com

\title{
EASTER IN LITHUANIA MINOR: CHANGES AND CONTINUITY IN TRADITION
}

\section{Kristina Blockytè-Naujokè}

\section{Klaipeda University}

\begin{abstract}
The goal of the article is to examine chronologically the specific nature of the Easter holiday in Lithuania Minor, to determine structural and functional changes in calendar traditions and rites. The main task is to differentiate and characterise models of the Lietuvininkai Easter holiday: archaic (from the first mention of holidays to the end of the 19th century); the end of the 19th century to the 20th; and the present time (since 1990).

KEY WORDS: Easter, Lithuania Minor, rites, calendar holidays.
\end{abstract}

\section{Anotacija}

Straipsnyje, pasitelkiant autentišką lietuvininkų medžiagą, analizuojama Mažosios Lietuvos Velykų specifika chronologiniu aspektu (nuo pirmųjų paminėjimų iki šių dienų), siekiama atskleisti bendruosius šventès raidos etapus ir šiuolaikines papročių transformacijas. Nagrinėjami pagrindiniai XIX a. pab. - XX a. Velykų modelio elementai, atskleidžiant struktūrinius ir funkcinius kalendorinių apeigų pokyčius. Taip pat siekiama išanalizuoti ir šiuolaikinius (nuo 1990 m.) šventės papročius bei aptarti etninès tradicijos tęstinumo galimybes šiu dienų šventès modelyje.

PAGRINDINIAI ŽODŽIAI: Velykos, Mažoji Lietuva, kalendorinès šventės, papročiai.

DOI: http://dx.doi.org/10.15181/rh.v28i0.2226

Due to historical circumstances Lithuania Minor, ${ }^{1}$ which was separated from the main part of Lithuania, developed its own distinct features of lifestyle, reli-

1 According to the Ethnic Culture Protection Agency, which determines the range of a given ethnic tradition, in 2003, Lithuania Minor included the city of Klaipeda/Memel, the Neringa and Pagègiai municipalities, the Šilute, Rusne, Kintai, Saugai, Juknaičiai and Usėnai districts 
gion and material culture. A structural analysis of some calendar holidays shows that the structure and local meaning of the same holiday in the same ethnic group can differ. It is worth noting that this happened because of the increased influence of urban culture and the transformation of rituals and their functions into entertainment in the early 20th century.

Rites of a communal nature dominated in the calendar holidays of Lithuania Minor: attending church on the morning of the holiday, whipping with juniper or birch branches on the first day of Easter (in some locations on the second), giving painted Easter eggs, the 'ai lalu lalu' ritual, waking the sleeping by beating them with birch branches on Easter morning and acquiring an egg from each sleeper, the ritual swinging on swings and various superstitions, and sayings and taboos. In the early 20th century, there were some tendencies in Lithuania Minor which led to the disappearance of ritual functions of calendar customs, the development of new functions, and the levelling of traditions. The tendency with unacceptable traditions was to individualise them, that is, to reinterpret, modify and adapt them to the needs or the entertainment of the community, thus destroying the local character of the holidays. An interesting phenomenon, however, came about towards the late 20th and early 21st centuries: residents of the region developed a need to construe an identity based on old traditions, despite the fact that Lietuvininkai had almost completely disappeared from the region by that point.

The subject of the article is the Easter holiday traditions and rites in Lithuania Minor.

The research objectives are to examine chronologically the specific nature of Easter in Lithuania Minor, and to determine the structural and functional changes in the holiday's traditions and rites.

\section{Tasks:}

- to discover and describe the Easter customs and rituals of the Lietuvininkai cited in old printed sources (from the first citation to the late 19th century), and to examine the significance of this content;

- to examine the main elements of the Easter holiday model of the Lietuvininkai from the late 19th to the 20th century, and to compare them with holiday elements from other regions, revealing structural and functional changes in calendar rituals; to examine modern Easter customs (from 1990 onwards) in Lithuania Minor, and to discuss the possibilities for the

of the Šilute region, the Lauksargiai district of the Taurage region, the Smalininki and Viešvilè districts of the Jurbarkas region, and the Dovilai, Kretingalé, Priekulé, Sendvaris, DauparaiKvietiniai and Agluonènai districts of the Klaipedda region. The other part of Lithuania Minor (the Königsberg area, formerly East Prussia, now Kaliningrad) now belongs to Russia (Jokubaitytė 2013, internet webpage: http://tiny.lt/5ucxmf5). 
continuity of the ethnic tradition via the reconstruction of customs in the model of modern celebrations.

Research data and methodology

The main source of data for the article is material from ethnographic expeditions and field studies carried out between 2007 and 2013. Based on the research problem and tasks formulated, a questionnaire called 'Calendar Holidays in Lithuania Minor: A Reconstruction of Traditions' was drafted. It was compiled by combining open, general, and specific questions regarding calendar holidays and the holiday rituals associated with them. Taking into consideration social, economic, cultural and political aspects, and in an attempt to analyse the adoption and transmission of the ethnic cultural and traditions of the Lietuvininkai in a historical context, respondents were presented with questions oriented towards comparative historical research. A total of 50 Lietuvininkai were interviewed at length using the set of questions drawn up by the author. Ethnographic field studies were conducted at 17 locations in Lithuania Minor (Vèlaičiai, Rusnè, Kintai, Katyčiai, Klaipėda, Šilutė, Jakai, Priekulè, Ketvergiai, Dovilai, Stankiškiai, Alka, Kukorai, Lumpėnai, Viešvilè, Smalininkai and Suvernai). The method of active participant observation was used for research, where respondents were selected using directed, intentional selection, in order to obtain the most accurate information with the most relevance to the object of the research. The criteria included, for example, whether the potential informant was born and grew up in the location being researched. For a variety of empirical causes (migration, deaths of old Lietuvininkai), it was often impossible to find the right kind of informants. The search for Lietuvininkai (born and raised in Lithuania Minor) was done by visiting administrative buildings and ethnocultural centres of the locations listed. Most of those questioned were elderly. It is notable that it was the older generation who mainly referred to themselves as residents of the Klaipeda area. They were also the most able to remember and describe old customs and rituals, and by comparing them to those of the present time, they greatly expanded the dimensions of the researcher's field of inquiry.

In order to get a more comprehensive picture of the subject of the research, an entire range of materials and sources was used, including written sources and materials from the Phonological Library of the Folklore and Ethnographic Manuscript Collection at Klaipeda University, the folklore manuscript collection and audio recordings library of the Institute of Lithuanian Literature and Folklore, and ethnographic field studies material preserved in the Ethnology Department of the Lithuanian Institute of History. In total, information from 245 in- 
formants was collected on the topic of calendar holidays in Lithuania Minor within the time frame of the late 20th and into the 21st century. Taking into the account the topic of the article, the empirical data collected during the analysis of sources and field research were systematised into topics that reflect the object, objectives and tasks of this article. A total of 148 ethnographic stories about the customs and traditions of the Lithuanian Easter celebration were collected. After systematising the empirical data, an analysis was performed. After classifying the data, the results are presented to reflect the real picture of the research phenomenon and the problems associated with it.

Based on the subject and tasks of the research, 11 employees responsible for organising holiday celebrations at the most active cultural centres in the towns and rural locations of Lithuania Minor were interviewed. Since Lithuania Minor is divided into sections, corresponding to the city of Neringa, the city and region of Klaipèda, the city and region of Šilute, and the city and region of Pageggiai, material was collected at Klaipeda Ethnocultural Centre and Dovilai Ethnocultural Centre, Šilutė Culture and Recreation Centre, the Vydūnas Culture Centre in Kintai, the Cultural Centre of the Municipality of Pagègiai, the Martynas Jankus Museum of the Bitenai municipality, and the Jurbarkas Regional Cultural Centre of Lithuania Minor. Data were collected based on unstructured interviews and a collection of photographic and video images. The collected material is also stored in the article under the VDU ER 2482 code.

Methods. The subject and problem of the article defined the methodology, based on a combination of several different methods. The corpus of Easter rituals, customs and traditions in Lithuania Minor was researched using analytical, interpretative and comparative methods. As empirical data were collected, methods for the analysis and synthesis of the contents of archival sources, academic literature and the news media and periodicals were also applied.

Review of research and sources

With regard to the presentation of the information, the sources can be divided into two groups: testimonies of secular-oriented clerical contemporaries (researchers of the 15th to the 19th centuries can be distinguished here), and sources providing retrospective information. Both source groups can be subdivided into groups of lower taxonomic level, depending on their origin, degree of informativeness, and objectivity. The sources in the first group include testimonies of the Christian clergy published in visitation writings, sermon collections, and various types of correspondence. This group of sources is characterised by fragmented information, revealing the relationship between the cultural environment of the population of those times and official Christian ideology. 
Ethnographic data about Prussian Lithuanians and the celebration of Easter have been found since the publication of the first Lithuanian book Katekizmas (Catechism) by Martynas Mažvydas (1547). ${ }^{2}$ He mentions the traces of paganism in Prussian Lithuanian customs of the time, and writes about a 'hymn sent' to the clergy and nobility, instead of the 'Easter egg-offering rite' (BRMŠ II 186).

Fragmentary information on the analysis of the Easter theme is available in the works of German researchers of the 17th to the 19th centuries: in 1690, Theodor Lepner wrote Prūsų lietuvis (The Prussian Lithuanian), an ethnographic work in German, where he described Easter games in Lithuania Minor: swinging, egg beating and rolling, and examples of Lithuanian wellwishing (Lepneris 2011, 195-196).

Carl Cappeller’s ‘Kaip senieji lietuvininkai gyveno’ (How Old Lithuanians Lived), published in the book Lietuvininkai. Apie Vakarų Lietuvą ir jos gyventojus devynioliktame amžiuje (Lithuanians. On Western Lithuania and its Inhabitants in the 19th century, 1904) is of special value. It contains information about egg painting at Easter, various games with eggs, and a description of Easter lulling customs in Lithuania Minor (Kapeleris 1970, 375-377).

The following publications are relevant to the topic of Easter in Lithuania Minor analysed in the article, as they emphasise old holiday elements: swinging, egg painting, activities with eggs, and festive routines: Lietuvininkų žodis (The Word of the Lietuvininkai, 1995); Lietuvininkų kraštas (The Region of the Lietuvininkai, 1995) and Lietuvininkų žemė (The Land of the Lietuvininkai), by Albertas Juška, Jurgis Mališauskas and Vladas Pupšys (1994).

Taking into account the objectives of the article, general works were also used to compare elements of the Lithuanian Easter celebration with festive elements in other regions: Lietuvių šventès: tradicijos, papročiai, apeigos (Lithuanian Celebrations: Traditions, Customs, Rites) by Pranè Dundulienė, Lietuvių papročiai ir tradicijos (Lithuanian Customs and Traditions) by Danutė Brazytė-Bindokienè, Lietuvos kaimo papročiai (Lithuanian Rural Customs) by Balys Buračas, Lietuvių kalendorinès šventès: tautosakinė medžiaga ir aiškinimai (Lithuanian Calendar Holidays: Folklore Material and Interpretations) by Jonas Balys, Kalendoriniai ir darbo papročiai Lietuvoje XIX a. pabaigoje - XX a. pirmojoje puseje. Jaunimo vakarèliai (Calendar and Work Customs in Lithuania in the 19th and Early 20th Centuries. Youth Parties) by Žilvytis Šaknys, and Tradicinių kalendorinių švenčių semantika (Semantics of Traditional Calendar Holidays) by Libertas Klimka.

2 Mažvydas M. Catechismvsa prasty szadei: 1547. In: Baltų religijos ir mitologijos šaltiniai: XVI a., t. II, 2001, p. 186. 
The book Velykų rytą lelija pražydo. Verbų sekmadienio, Velykų, Jurginių papročiai ir tautosaka (A Lily Bloomed on Easter Morning. Palm Sunday, Easter, St George's Customs and Folklore) is also valuable for the topic of the article. The book is based on manuscripts and ethnographic material collected during expeditions. It presents sources accumulated in field research revealing the differences between the Lithuanian ethnographic regions.

The atlas Lietuvos kultūra. Mažosios Lietuvos ir Žemaitijos papročiai (Lithuanian Culture. Customs of Lithuania Minor and Samogitia) was published in 2012, in which Žilvytis Šaknys discusses the initiation and calendar customs of young people in the area under study. However, it should be noted that most of the informants are not Lithuanians, but simply young people living in these areas today.

Based on this review of research sources, it can be stated that the Easter holiday traditions constantly presented interest and were researched, but information about festive customs in Lithuania Minor, especially their regional peculiarities, is very fragmentary.

Chronological Boundaries and Essential Stages in Changes in the Easter Customs of the Lietuvininkai

The traditions of calendar holidays in Lithuania Minor between the 16th and the 20th centuries are a distinct expression of Lithuanian culture relating to the historical, political, social and religious development of the region. Based on written sources from Lithuania Minor and contemporary oral ethnography, the examination of larger Lietuvininkai holidays makes it clear that the ritual celebratory activities constitute a cycle of actions and events accumulated and polished over the centuries, in which every act has a specifically defined time and place.

Taking into account the chronological boundaries of the collected material, the article constructs the following models of the Easter celebration in Lithuania Minor:

- archaic (16th to late 19th centuries), in which the distinct culture of the Lietuvininkai is reflected;

- late 19th and 20th centuries, characterised by cultural transformations (rejecting specific regional features and levelling of traditions);

- contemporary (from 1990 to the present day), in which traditions are 'discovered/invented' (older elements take on new meanings, new holiday models are constructed). 
First mentions of the archaic Easter model of the Lietuvininkai

The archaic Easter holiday model reflects the material and spiritual heritage, identity, rituals, customs and traditions of the Lietuvininkai. The following elements can be distinguished as characteristic of the archaic model of Easter celebration in Lithuania Minor: egg painting and various actions with eggs (presenting them as a gift, competing by hitting them against each other, rolling); processions of lalauninkai; swinging on swings; pouring water on each other, and other water-related rites; making offerings to ancestral spirits.

\section{Easter celebration customs in the 16th to the 19th centuries}

\begin{tabular}{|c|c|c|c|c|}
\hline & 16th c. & 17th c. & 18th c. & 19th c. \\
\hline $\begin{array}{l}\text { Egg painting } \\
\text { with its archaic } \\
\text { semantics, and } \\
\text { various associ- } \\
\text { ated activities }\end{array}$ & $\begin{array}{l}\text { LM priests } \\
\text { and nobles } \\
\text { gave them to } \\
\text { their fellows } \\
\text { (Mažvydas: } \\
\text { BRMŠ II } \\
\text { 186). }\end{array}$ & $\begin{array}{l}\text { Dyed with soot or } \\
\text { herbs. Boiled eggs } \\
\text { were hit against } \\
\text { each other, dyed } \\
\text { or rolled on the } \\
\text { ground (Lepneris } \\
\text { 2011, 196). }\end{array}$ & $\begin{array}{l}\text { Mention is made } \\
\text { of dyeing eggs with } \\
\text { onion shells and } \\
\text { inscribing them } \\
\text { with wax (Golem- } \\
\text { biovskis: BRMŠ IV } \\
\text { 135).* }\end{array}$ & $\begin{array}{l}\text { Eggs were hit } \\
\text { against each other. } \\
\text { Dyed one colour; } \\
\text { inscribed with } \\
\text { names, house- } \\
\text { holds, years } \\
\text { (Kapeleris 1970, } \\
376 \text { ). }\end{array}$ \\
\hline $\begin{array}{l}\text { Processions } \\
\text { of lalauninkai } \\
\text { (lalauti, to go sing- } \\
\text { ing from door to } \\
\text { door and collect } \\
\text { presents) }\end{array}$ & & & & $\begin{array}{l}\text { Young people } \\
\text { visited households } \\
\text { and were rewar- } \\
\text { ded with wine, } \\
\text { cakes, money or } \\
\text { eggs from house } \\
\text { owners } \\
\text { (Kapeleris 1970, } \\
\text { 375). }\end{array}$ \\
\hline $\begin{array}{l}\text { Ritual swinging } \\
\text { on swings }\end{array}$ & & $\begin{array}{l}\text { Swings were put } \\
\text { up in the yard } \\
\text { for the festivities; } \\
\text { young people } \\
\text { swung } \\
\text { (Lepneris 2011, } \\
\text { 196). }\end{array}$ & & $\begin{array}{l}\text { Swings were built } \\
\text { in the barn; young } \\
\text { people swung } \\
\text { (Kapeleris 1970, } \\
\text { 377). }\end{array}$ \\
\hline
\end{tabular}




\begin{tabular}{|l|l|l|l|l|}
\hline $\begin{array}{l}\text { Libation and } \\
\text { other rituals in- } \\
\text { volving water }\end{array}$ & 16th c. & $\begin{array}{l}\text { 17th c. } \\
\text { People poured } \\
\text { water over each } \\
\text { other and threw } \\
\text { girls into the water } \\
\text { on the second and } \\
\text { third days of Eas- } \\
\text { ter; it was said that } \\
\text { on a day called Ice } \\
\text { Day you could not } \\
\text { work because the } \\
\text { ice was believed } \\
\text { to destroy crops } \\
\text { (Karpis: BRMŠ IV }\end{array}$ & $\begin{array}{l}\text { On the second and } \\
\text { third days of Easter } \\
\text { people poured wa- } \\
\text { ter over each other, } \\
\text { and sometimes } \\
\text { into the water; on } \\
\text { the fourth day of } \\
\text { Easter, Lada Day, } \\
\text { no one worked, } \\
\text { because of the fear } \\
\text { that storms would } \\
\text { damage the crops } \\
\text { (Čerskis 1830, 25). }\end{array}$ & \\
\hline $\begin{array}{l}\text { Sacrifices to the } \\
\text { spirits of the dead }\end{array}$ & & $\begin{array}{l}\text { Men and women } \\
\text { made offerings to } \\
\text { the spirits of the } \\
\text { ancestors, espe- } \\
\text { cially at Easter, } \\
\text { Christmas and All } \\
\text { Saints, and prepa- } \\
\text { red a feast for them } \\
\text { (BRMŠ II 616). }\end{array}$ & \\
& & & \\
\end{tabular}

This custom could go back to the customs of the early 19th century, as Lukasz Golębiovski lived at the turn of the 18th and 19th centuries (1773-1849).

** This custom could go back to the customs of the early 19th century, as Stanislav Czerski (1777-1833) was born in the late 18th century, but the book Žemaičiu vyskupystès (The Samogitian Dioceses), with a description of customs, was published in 1830.

Judging by a letter Martynas Mažvydas wrote in 1549, in which he stated that he was sending a psalm instead of 'an Easter egg' (Velykų pauto) (BRMŠ II 186), we can assume that in the 16th century it was customary for the clergy of Lithuania Minor to give Easter eggs as gifts to their fellows; until the 20th century, egg imagery was believed to have magic life-giving powers. It can be assumed that the gift of an Easter egg originated from the rite of offering bull's testicles (pautu aukojimo apeiga), which is related to fertility, and was supposed to ensure the cattle's fertility (Balsys 2010, 174-175). According to Prane Dunduliené, ethnographic data show that the custom of giving an Easter egg as a gift was followed until the Second World War, and in some regions even later (Dundulienè 2008, 128).

In the 17th century, Theodor Lepner described games with Easter eggs in Lithuania Minor: 'On Easter Day they hit hard-boiled eggs against each other, dye 
them with soot or herbs; the egg that gets broken belongs to the one who broke it. Or they roll them on the ground' (Lepneris 2011, 196). ${ }^{3}$

Processions of lalauninkai ${ }^{4}$ were also related to the custom of giving eggs as a gift, which had a ceremonial significance. The ceremonial visiting of households with greetings and songs, known to many agricultural nations, had a clear magic function, and could be performed on various calendar holidays in order to ensure a good harvest.

In the mid-19th century, Cappeller recorded this rite of Easter lalavimas in Lithuania Minor: ${ }^{5}$ 'In the evening, young people gathered in groups and went to other households, as was the ancient way, to sing praise, laluoti. So they "sowed" grain under the owner's window and begged him to sing. If the lord of the house said ' $j e$ ', then they started singing the following song: "Good evening, good lord! Ei lalo / Good evening, good lord! / Are you already asleep? - Ei lalo / Wake up, get excited!", (Cappeller 1970, 370).

Lalavimas, which is known from 19th and 20th-century sources, involved a group of people, but the participants differed in the importance of their function, which perhaps also shaped the attitude towards them, as well as the evaluation of the custom itself. And although the participants in lalavimas may have been distinguished from the sacred guests who brought good news, their visit was supposed to ensure success on the farm. In addition, the ideological aspect was also important: participants in lalavimas brought good news to Christians about Christ's resurrection from the dead; but by the early 20th century the situation had changed: lalavimas was forbidden to the clergy, they were not allowed to sing praise, and no gifts were given to them; lalavimas was also not tolerated by rich society, associating it with begging (Daugirdaite 2001, 9).

The structure of the Easter household visit: 1) the owner's permission to sing praise is requested; 2) a ceremonial text is performed as well-wishing; 3) gifts are requested/demanded. Lalinkos, songs sung to girls as potential brides, begin to be sung by the girls themselves (Daugirdaite 2001, 9). In Lalinkos, the youth of the girls is praised, animals are honoured by the farmers, and green fields are symbolically indicated by the time of various jobs. For example, one lalinka,

3 See Blockytė-Naujokè K. Easter Egg Symbolism in Lithuania Minor. Acta humanitarica universitatis Saulensis. Mokslo darbai. Regionas: istorija, kultūra, kalba. No 27 (2020), pp. 225241.

4 It should be noted that the custom of lalavimas was still known in the early 20th century almost throughout Aukštaitija (except central Lithuania), the western part of Samogitia, and in Suwalki (Kudirka 1992, 70). In the Punsk area and in Dzūkija, participants in lalavimas occasionally appear even now, only they sing less (Vyšniauskaite 1993, 70; Kudirka 1992, 70).

5 A similar song from the Tilže area is performed by V. Kalvaitis (see Kalvaitis V. Prussian Lithuanian Songs. Tilžè, 1905, No 4). 
heard and recorded by Cappeller in Lithuania Minor in 1845, has the following lyrics: 'St George shook the dew, - ei lalo / St John brought the manure, - ei lalo / St James reaped the rye, - ei lalo / St Anne tied rye ears into stacks, - ei lalo' (Marcinkevičienè 2006, 154). Lalavininkai, like Christmas carol singers, must be rewarded: it is a sacral ceremony aimed at making sure the well-wishing of the greeters will come true (Vyšniauskaitė 1993, 70-71).

Lepneris mentioned the custom of swinging ${ }^{6}$ at Easter: 'They have these games as entertainment: swings are put up in many of their yards for Easter, Pentecost and St John's Day. They are made from strong posts, dug deep into the ground, three at each end, their tops tightly tied with twisted twigs. A strong crossbar is tightly tied at the top; the swings are about 15 feet high and 13 feet wide. The person wishing to swing sits on a board, well attached on both sides to birch or oak planks at the crossbar, but free to rotate; two men stand beside of the board, and, holding the end of the rope, toss the person sitting on the swing high into the air' (Lepner 2011, 196). One of the most important purposes of the archaic festive ritual is to preserve the existential moments of farmers' lifestyles, and to pass them on to the next generation, so that the ritual is constantly (annually) repeated, and thus ensures the survival of the whole community and its individual members. For centuries, the existential basis of the nation was agriculture; therefore, most attention on calendar feasts was paid to the future harvest, the growth of animals, the health, success and continuity of community members, and all kinds of fertility. Swinging was one of the main magic activities to improve the flax harvest, and this rite was alive until the end of the 19th century.

An important source for learning about the world-view of the 18th-century Lithuanian peasants is the annual reports by missionaries from the Vilnius and Kražiai Jesuit colleges, who carried out missionary work in Samogitia and elsewhere in Lithuania, 'Jesuit Annual Reports' (BRMŠ II 616). It was obvious that in the 17th century the Lithuanian countryside still had remnants of the old pagan religion (Marcinkevičienè 2006, 154). Special rites and feasts honoured the spirits of the dead during the great holidays: 'Meanwhile, other men and women illegally offered sacrifices to the spirits of friends and ancestors every year, especially at Easter, Christmas, and All Saints, and prepared feasts for

On page 543 of 'A Description of a Journey to the East', [Adam] Olearius mentions that though the Muscovites also had high swings, they were arranged differently, as could be seen from a copper engraving. "They [the Lithuanians] put across a plank board, alternate between stepping on its two ends, and thus fly into the air, albeit not high. They play the game "Third Catches". They hide a blooming flower, and ask to guess who has it, and have more such games. Children roll egg-sized or smaller wheels, driving them with a long pole to roll as far as possible' (BRMŠ 2003, 364). 
them' (BRMŠ I 633). Eventually, through the efforts of the Jesuits, these 'illegal' rites were replaced by the distribution of alms to the poor, and other devotional activities.

It should be noted that older written sources mention Vèliu Velykos ${ }^{7}$ (the Easter of Spirits) as one of the greatest holidays. In the early 16th century, the dead were commemorated on great Church holidays: Easter, the Day of the Dead and Christmas were equivalents. In Lithuania Minor, Tykioji Pètnyčia (Silent Friday) was exceptional in that parents would take their children to the cemetery to show them their relatives, where opapos and omamos were laid to rest, and it was believed that on that day they left purgatory. So in Lithuania Minor, Spirit Easter was associated with the belief that spirits visited the living on that day. Spirit Easter was observed until the fourth decade of the 20th century. Thus, summarising examples of archaic celebratory patterns, we can claim that until the late 19th century, the transformational processes in Lithuanian Easter customs did not happen rapidly.

Easter as observed by the Lietuvininkai in the late 19 th and 20 th centuries

Almost all elements typical of the archaic celebration model of Lietuvininkai can be found in the structure of Easter festivities in the 20th century: egg dyeing and all things related, swinging, and using water in various rites. However, almost all these rites lost their initial ceremonial significance, and began to change into entertainment.

Didžioji savaite (Holy Week) before Easter was a time for cleaning up after winter: 'The pre-Easter preparation was special: a pig would be slaughtered, family members would scrub the house all week, and mother would change the curtains. In the oven, pork would be cooked with cabbage and potatoes, pastries and cakes would be baked, and beer would be brewed' (VDU ER 2482 [born in 1927, in Aukštumala, Šilute district]). The last pre-holiday days were rich in various beliefs and rites, in which the Christian theme of the Resurrection of Christ was mixed with the oldest foretelling of spring awakening nature, working the earth, magic activities aimed at a future harvest, and taboos.

In Lithuania Minor, this week was called Tykioji (Silent), and the main days of the week had names: Great or Green Thursday (Ketvergis, Četvergis), Great or Silent Friday (Tykioji Pètnyčia): 'The whole week before Easter was called "the

7 This name was first mentioned in the 17th century in the Lithuanian-German dictionary, then later in 1747 and 1800 in the dictionaries by P. Ruigis and K.G. Milkus respectively. In 1894, E. Miežinis also provided synonyms for 'Spirit Easter' in the Lithuanian-Latvian-Polish-Russian dictionary: vẻliu pètnyčia 'spirit Friday', and vẻlių durelès 'spirit doors'. 
quiet week". All kinds of noise were avoided, like songs and dances' (KUTRF 408 / KUTR 66 [born in 1906 in Antšvenčiai, Tilžè-Ragainè, living in Smalininkai since 1950]). In Lithuania, house cleaning started on Wednesday, and in Lithuania Minor on Green Thursday: 'On Green [Maundy] Thursday, potted plants were re-planted. Windows had to be cleaned, yards swept, and mangers cleaned of rubbish' (KUTRF 408 / KUTR 66 [born in 1906 in Antšvenčiai, Tilžè-Ragainè, living in Smalininkai since 1950]).

It is important to mention that for the Lietuvininkai, Maundy Thursday was a time for calm and concentration: 'On that day, those who wished would go to the table of God, for the Last Supper. Father would go to confession on Thursday, well, but the priest would never have any confessions "for his ears only", it was a short Mass, getting ready for the next day' (KUTRF 408/ KUTR 66 [born in 1906 in Antšvenčiai, Tilžè-Ragainè, living in Smalininkai since 1950]).

Throughout Lithuania on Maundy Thursday, water (especially running water) was known for its power to heal and cleanse the skin, and make the face younger (Balys 1993, 118). However, in Lithuania Minor, special attention was paid to water on Good Friday: 'On Silent Friday, we would go to the stream to bathe; it was said that the water was sacred there, you would be blessed by God, and happy; so we, the children, would get up before sunrise, and go there to wash. We sincerely believed that we would be happy after bathing' (KUTRF 1127/ KUTR 210 [born 1940, Kintai]). It should be mentioned that for the Lietuvininkai, Good Friday was a holy day, when fasting was observed and people went to church to pay tribute to the suffering of the dying Christ: 'Before Easter, Good Friday, it was a sad day, then you were only allowed to drink water on your way to church. We went to confession, and you couldn't eat, Father wouldn't let us' (KUTRF 1101 / KUTR 205 [born 1932, Lumpènai village, Pagėgiai municipality]). For the people of Lithuania Minor, all work was prohibited on that day: 'On Good Friday you mustn't work at all, you must pray and go to church, for a holy dinner. You can't spin or weave, it's a big holiday on Good Friday' (KUTRF 407/ KUTR 65 [born 1909, Ropkojai, Pagègiai district]). Because of its holiness and the serenity of the rites, Good Friday in Lithuania Minor was called a halffeast. It stood out by its asceticism and the special mood of the great holiday, waiting for Easter (Marcinkevičienè 2006, 92).

It should be noted, though, that water was believed to have a special power on Holy Saturday, and the scale of its use was very wide. According to the informants, it can be said that before the Second World War, it was still believed that even simple water had power on Easter Sunday, that is, even water not blessed in church (Marcinkevičienè 2006, 105). This is confirmed by a custom in some places in Lithuania Minor that is alive to this day, of going to the sea early on 
Easter morning, and bringing home water from the sea or a river or a stream, as it was believed to have exceptional powers to help people: 'At dawn on Easter morning, adults and children ran to the river or the lagoon to bathe, believing that it brings health and beauty. The water was considered sacred, it was taken home to water flowers, and was kept in a container all year round in case of illness' (Čepienè 2002, 86). Thus, Easter water had healing and cleansing powers attributed to it: 'He who is freckled has to bathe in a flowing stream on Easter morning at sunrise' (KUTRF 405 / KUTR 65 [born 1932, Ropkojai, Pagègiai district]). As early as the 20th century, in the Tilžè area, there was an ancient custom before Easter: at midnight, to go to a stream, and silently bring home water, a cure for various diseases: 'On Easter night, at midnight, you have to take some water from the river (a flowing spring would be best), quietly, not saying a word, and bring it home and keep it, because water protects from all diseases' (LTR 604, 235).

However, according to the material submitted from the 20th century, we can claim that water becomes most powerful on Easter morning, before sunrise: 'We went to get holy water where a rivulet or a stream flows. In the morning we take water before sunrise, in the morning children have to bathe' (KUTRF 85b / KUTR 28 [born 1916, Žemaitkiemis, Šilutè district]).

This perception of the holiday exclusivity of the season, as opposed to everyday life, persisted until the early 20th century. At Easter, an exceptional holiness was attributed to the 'dancing' or 'colour-changing' sun: 'People said that in the early morning, at dawn on Easter morning, the sun is so happy at the rebirth of Christ that it dances around the sky and is joyful' (KUTRF 408/ KUTR 66 [born 1906, Antšvenčiai, Tilžè-Ragainè district, since 1950 living in Smalininkai]). It can be stated, for example, that images emphasising the uniqueness of Easter morning, the time of sunrise, were based on a mythological perception of time, and the effectiveness of magic rites was ensured by the sacral properties of mythologised time. Thus, until the mid-20th century in Lithuania Minor, sunrise was considered to be the best time for individual Easter celebrations.

Egg dyeing on Holy Saturday. In the early 20th century in Lithuania Minor, people started dyeing eggs, using not only natural but also chemical dyes: 'Egg dyeing was a feminine job. Older children could also do it. Mother had dyes she had bought, or used onion peel, and sometimes scraped the eggs as well' (KUTRF 1125/ KUTR 210 [born 1933, Šūdnagiai, Priekulè area]). On Holy Saturday, people in Lithuania Minor dyed eggs various colours (usually with chemical dyes or onion peel), but not with dotted patterns as in Greater Lithuania: 'We take a simple bucket, add iron, black alder, and bark that turns red, and then more black alder, leave it for one or two weeks, and then pour the liquid 
into wooden pots, put the Easter eggs in, and soak them. And then boil them in onion peel' (KUTRF 1080 / KUTR 201 [born 1936, Timsriai, Natkiškè]). 'They melted tallow and wrote words with a stick (the name, household, etc) on a painted egg, then dipped it into salty water, and left it for a few hours. When the acid-affected egg was taken out, the inscription was visible' (MLE 2009, 682). It is of note that some families did not paint eggs, because dyeing was associated with the sufferings of Christ. ${ }^{8}$

The sacredness of the festive holiday is also emphasised in prohibitions defining human behaviour. During the Easter holiday period, it was prohibited to do everyday chores; farm work was limited. In the early 20th century, those prohibitions were based on potential risks: natural disasters, the death of a loved one, or other events that were not wanted in the life of a farmer. It is noted that in some parts of Lithuania Minor, it was forbidden to use sharp tools' at Easter: 'On Easter morning you would never find a knife, they were all hidden. All you could find was a fork. It was forbidden to cut anything. It was believed that if you cut yourself, it would be fatal' (KUTRF 1069/ KUTR 198 [born 1937, Palendriai, Šilute district]). Any exceptional act in the holiday period would gain continuity in the future: 'On Easter morning, before sunrise, you had to sweep the house while naked, and then, still naked, throw the swept litter over the neighbour's fence, to avoid fleas that year' (LTR 604, 233).

\section{Easter celebration routine}

The social behaviour stereotypes of the Lietuvininkai demanded that the holiday be celebrated 'as parents and grandparents celebrated'; therefore, the celebration of Easter in Lithuania Minor was held for three (in some places two) days in a row: 'The first celebration day was in the church, on the second day of the celebration we would go and visit someone, or someone would visit us, and the third day was for resting and cleaning up' (KUTRF 203/ KUTR 43 [born 1909, Šyša, Šilute district]).

After coming home from church, people in Lithuania Minor would have breakfast: 'For Easter breakfast, hay is put on the table, then it is covered with a tablecloth, and an egg is put on it for each person' (KUTRF 847 / KUTR 149 [born 1923, Jokšai, Priekule area]). It was quite usual to start with eating an egg, but in some families they would leave eggs for the second day: 'We would not

8 See Blockytė-Naujokè K. Easter Egg Symbolism in Lithuania Minor. Acta humanitarica universitatis Saulensis. Mokslo darbai. Regionas: istorija, kultūra, kalba. No 27 (2020), pp. 225241.

9 According to Balys, sharp objects were not used, because spirits could be injured (Balys 1993, 27). 
eat Easter eggs on Sunday. They would be left for Monday, when the relatives and neighbours would come and visit, and children from the village would come and collect eggs' (VDU ER 2482 [born 1927, Aukštumala, Šilutė district]). It is interesting that in some parts of Lithuania Minor, the festive breakfast would start with drinking warm milk: 'When we all gathered at the table, we would first be handed bowls with warm boiled milk, no one would use cups or anything, we would drink from the bowls, each and every one of us' (KUTRF 100, 102/ KUTR 32 [born 1909, Pažvelsis, Klaipeda district]).

It was forbidden to visit someone on the first day of Easter, so children would play games: 'Easter was a silent celebration, we would read books, play dominoes at the table, and all kinds of board games, and we would think up various games with dice' (VDU ER 2482 [born 1927, Aukštumala, Šilute district]).

\section{Whipping with a juniper or birch twig}

Lithuania Major had a custom of being whipped with an Easter palm. ${ }^{10}$ However, there was no such tradition in Lithuania Minor. On the first day of Easter (in some parts on the second), people would whip one another with juniper or birch twigs: 'A few weeks before Easter, we put birch twigs in bottles and kept them in a warm hut, and the buds exploded with green leaves, thus turning into lively, fragrant Easter whips for my mother and aunts, to greet them for the Easter holidays' (LŽ 1995, 57). Everyone tried to get up earlier and whip those who were still asleep, or neighbours. Juniper twigs, called verbos (singular verba), were also used for whipping: 'We picked only green ones. Usually, they weren't coloured as they are now; well, an occasional flower could be tied in, but we picked everything ourselves, those verbos from juniper' (KUTRF 1080 / KUTR 201 [born 1936, Timsriai, Natkiškès]).

According to testimonials from the 20th century, the custom was the same as it is nowadays, to try and catch members of the family who were still asleep, and whip them with birch twigs while chanting: 'I am whipping you on Easter morning with a green birch twig. I demand five eggs and a piece of lard, and I'll leave satisfied' (KUTRF 203/ KUTR 43 [born 1909, Šyša, Šilutè district]).

People of Lithuania Minor started expressing Easter greetings, velykauti, mostly on the second day of Easter (sometimes on the first), saying: 'I am a

10 The ethnologist Balys explains the custom of juniper whipping as follows: 'Verba is a magic green twig which, when used for whipping, gives a person or animal the power of growth and life, while also protecting them from disease. Springtime is best for this. So the older view holds that whipping brings growth, health and beauty. Under the influence of Christianity, the power to scare away or cast out evil spirits, especially with its smoke, was later attributed to verbos. Finally, out of the serious rites performed by adults, only a fun means of awakening sleeping children was left, informing them of the approaching Easter' (Balys 1993, 115). 
child as small as a bean pod. I went to the manger, picked a flower, threw it on the road, lilies bloomed, but not just because of me. Let everyone be happy, and give me Easter eggs, hard-boiled and painted with writings' (KUTRF 403 / KUTR 65 [born 1933, Kažemèkai, Šilutè county]). Similar Easter oratories were recorded by Balys, but those were pronounced not only at Easter, but also on Palm Sunday, whipping the family members with a juniper twig (Balys 1993, 114). Participants in lalavimas often used the same oral formula (Balys 1993, 114). It is noted that people of Lithuania Minor beat eggs with a birch twig: 'We would only go to velykauti at Easter. We would bring the twigs early, they had to be full of leaves, and then we would go, recite a poem, and then give Easter eggs. Then you had to whip your legs with the birch twigs, and say: "Šmok Oster, band Oster" (which means "colourful Easter"). I was told: "Take out the basket" and twenty raw eggs, ten painted eggs, two kilos of lard, and half a pie would be put there. I could barely lift it. I was still small. And if you went to strangers, you could get two eggs each, but we didn't go, mother wouldn't let us' (VDU ER 2482 [born 1927, Aukštumala, Šilutè county]).

The most popular activities with painted eggs, crushing and rolling, ${ }^{11}$ were a great part of the ancient spring celebration rites. ${ }^{12}$

Easter Bunny. In Lithuania Minor, Easter eggs would be hidden in the garden or near the barn, in piles of hay or various herbs, or in nests made of moss. Children were told that they were left there by the Easter bunny: 'We believed so much in the bunny our parents would tell us "Children, behave, or else the bunny won't bring you eggs!" and then we would go and try to find the eggs! There were so many nests: red ones, and white ones, and purple and green ... then we would count who had found the most eggs. And now I put a box with eggs under a tree for my grandchildren, then we make nests, and in the morning they find eggs' (VDU ER 2482 [born 1927, Aukštumala, Šilutė area]). ${ }^{13}$

Swings. Swings were put up all over Lithuania for Eastertide. According to Angelè Vyšniauskaitė, 'Swings were used by one, two or four people at a time.

11 In Germany in the late 19th and early 20th centuries, eggs were also rolled, and hitting egg against egg also happened: first with the sharp end and then with the blunt end. The winner kept the broken egg. A favourite game of older boys since as early as the 16th century was a game called Eierlesen (Spamer 1935, 114). Around 100 to 200 eggs were placed in two rows at a certain distance from each other. They had to be collected in a basket: whoever collected his row first would be the winner. It is of note that girls performed spells with eggs: they threw an egg over the threshold on to a path, and whoever passed it would become their husband (Spamer 1935, 114). In the 20th century, eggs were replaced in games by oranges.

12 See Blockytė-Naujoke K. Easter Egg Symbolism in Lithuania Minor. Acta humanitarica universitatis Saulensis. Mokslo darbai. Regionas: istorija, kultūra, kalba. No 27 (2020), pp. 225241.

13 Ibid. 
Researchers explain this custom by the human desire to stimulate the growth of vegetation and the health of animals' (Vyšniauskaite 1993, 68). In Lithuania Minor, the joy of Easter was also unimaginable without swings. In many villages, there were swings all the time; elsewhere, groups of youths would make them before Easter. Boys and girls would gather at a swing, shepherds having fun with one another. Often, when spring was cold and late, swings were hung in the barns: 'At Easter we put up a swing in the barn: Father had to make a big swing, our daddy. Five or six of us could sit on the swing. It had such a big board. Two ropes. So we would sit there and swing a lot. And what was it attached to? Well, up there, to the beams. Crowds of young people gathered, and children were only allowed to swing on the second or third day' (KUTRF 405/ KUTR 65 [born 1932, Ropkojai, Pagėgiai area]).

\section{The modern Easter model of the Lietuvininkai}

The modern model of holidays in Lithuania Minor tries to combine ethnic traditions with the needs of the modern consumer society. In the modern Easter model of the Lietuvininkai, we can single out a couple of kinds of celebration: educational activities before the celebration, a family celebration at home, and celebrating the Sunday of Divine Mercy (the first Sunday after Easter) in public places.

Easter in Lithuania is unimaginable without Easter eggs. Of course, the techniques of decorating eggs have slightly changed, but the activities remain identical: Easter eggs are given as presents, and various games are played with them, rolling and trying to crush the opponent's eggs. However, in Lithuania Minor, the more archaic layer of Easter customs is almost extinct: lalavimas, the custom of velykavimas, swinging, various spells, superstitions, and prohibitions.

A week after Easter, the Sunday of Divine Mercy (Atvelykis) ${ }^{14}$ is celebrated. It is also called Children's Easter (Vaikų Velykèlès, Velykikès, Mažosios Velykèlès). Since ancient times, this was the final day of a long Easter celebration, which was dedicated to children. Women dyed eggs, but only children played games. Atvelykis was the end of the festive visits of relatives and neighbours, and a time

14 In neighbouring Slavic lands, this day is called Pravadais, as in Dzūkija and eastern Lithuania. It is related to the 'going away' of the dead, the custom of seeing them off. It was believed that the spirits of the dead who returned home for Easter would leave the living at Atvelykis. In Belarus, in the evening, women would prepare bundles of food, and on Sunday would go to the cemetery and eat at the graves of their kin. Three or four eggs would be left on the grave. Church services would also take place in the cemetery, after which the eggs from the graves would be given to beggars. Similar Atvelykis customs existed in Russia and Ukraine (Marcinkevičienè et al. 2006, 233). 
of rest. It was basically a repetition of the folk Easter customs, but without the ceremonial symbolism.

It is notable that the material analysed from the 20th-century Lietuvininkai made no mention of the Atvelykis celebration. However, after ethnocultural centres started to organise this celebration, the tradition also became popular in Lithuania Minor after 1991. The annual celebration of the Sunday of Divine Mercy includes a children's fair (children sell their handicrafts, dye and roll eggs, and play various games), people swing on swings, and play old games that were played by shepherd children. Educational activities, teaching people to dye eggs, to make nests from hay, to mould birds from clay, etc, are becoming more and more popular. Performances by folk ensembles and egg rolling competitions also take place during this festival. Thus, some forms of the celebration may claim to continue the old Easter traditions, but also create new ones.

Since 1992, the holiday of Atvelykis has been a tradition nurtured by the ethnocultural centre of Klaipeda city municipality, which invites residents to meet in the Old Town. A dyed egg contest takes place in the festival, we are invited to swing as high as possible to be healthy and happy all year round, traditional folk games are played, and a crafts fair is organised (VMU ER 2482, Ethnocultural Centre of Klaipèda City Municipality). Since 2005, the children's Easter celebration has been organised by the educational programme and the Dovilai Ethnocultural Centre (VDU ER 2482, Dovilai Ethnocultural Centre). The Nida Culture and Tourism Information Centre Agila also organises Atvelykis celebrations, where folk ensembles perform and egg rolling competitions take place. However, instead of the Easter bunny, a character typical of all of Lithuania emerges, the Easter grandmother. Pagégiai Municipality Cultural Centre has also celebrated Atvelykis since 2006, when a children's fair takes place, and children from schools sell their handicrafts, paint and roll eggs, and play various games (VDU ER 2482, Ethnocultural Centre of Klaipėda City Municipality). So all forms of this celebration can claim to be a continuation of the old Easter traditions.

Conclusions

1. Holiday traditions in Lithuania Minor between the 16th and the late 19th centuries are a distinct expression of Lietuvininkai culture, related to the historical, political, social and religious development of the country. Holiday rituals were extremely important, and thus the change in the Lietuvininkai tradition of customs was slow.

2. Characteristic elements of the Easter holiday model are as follows: egg 
dyeing with its archaic semantics and various associated activities (giving eggs away as gifts, painting and rolling them), the 'ai lalu lalu' ritual, swinging on swings, libation and other rituals involving water, and sacrifices to the spirits of the dead. The same types of customs practised on other major Lietuvininkai holidays also appear in the ritual structure of Easter, with the emphasis on the sacred time, beliefs and taboos regarding individual behaviour, and rituals of a communal nature: going to church in the morning of the holiday, and whipping with birch or juniper twigs on the first (or second) day of Easter.

3. We can observe the gradual disappearance of the ritual functions of calendar customs, the formation of new functions, and the levelling of traditions in Lithuania Minor in the late 19th and the early 20th centuries. In the 1920s and later, we observe the loss of the former existential importance of the Lietuvininkai ritual tradition, when the rituals turned into customs with new symbolic meanings and forms that replaced the content of the former rituals, and a newly formed regional identity replaced ritual functions.

4. Contemporary holiday models of Lietuvininkai attempt to reconcile ethnic traditions with contemporary social needs. Several forms of celebration can be differentiated in the contemporary model of the Lietuvininkai Easter: a family holiday at home, educational activities before the holiday, the public celebration of Atvelykis (the Sunday of Divine Mercy in the Western Christian tradition, or the Sunday of St Thomas in the Eastern, also known as the Second Sunday or Antipascha), the latter is exclusively maintained institutionally, at the initiative of ethnocultural centres and folklore collectives. These forms of holiday that appear in the cultural space exist as a demonstrative and educational measure, informing present-day society of the traditions of long ago, and act as a symbol of strength of the pan-Lithuanian ethnic identity. These events differ from the holiday tradition, in terms of both location and structure.

5. When comparing ethnographic data from Lithuania Minor and Greater Lithuania from the late 20 th and early 21 st centuries, we can see clearly that a large area shares similar calendar holiday customs. Interpretations of calendar cycle rituals provided by informants are always connected with the social and cultural environment in which they live. As a result of the above-mentioned comparison, the following statement can be made: Easter holiday customs are essentially the same throughout Lithuania, and the differences encountered are slight, and mostly connected with the social 
environment of families and religious details.

6. At the turn of the 20th and 21st centuries, cultural and educational institutions have become perhaps the most important factors in preserving the vitality of symbolic forms of ethnic culture. Although the institutionally organised calendar holidays follow a set of more or less standard scenarios throughout Lithuania, the centralised organisation of activities by cultural centres could still encourage the celebration of local forms of Lietuvininkai traditions, by emphasising typical elements of the Lithuania Minor holiday.

Abbreviations

KUTRF - Klaipèdos universiteto tautosakos ir rankraštyno fondas (Folklore and Manuscript Fund of Klaipèda University)

VDU ER - Vytauto Didžiojo universiteto etnologijos rankraštynas (Ethnology Manuscript Department of Vytautas Magnus University)

LLTI - Lietuvių literatūros ir tautosakos institutas (Institute of Lithuanian Literature and Folklore)

LII - Lietuvos istorijos institutas (Lithuanian Institute of History)

LTR - Lietuvių tautosakos rankraštyno duomenų bazè (Lithuanian Folklore Archive Database)

\section{Literature}

Balys 1993 - Jonas Balys. Lietuvių kalendorinès šventès: tautosakine medžiaga ir aiškinimai. Vilnius: Mintis.

Balsys 2010 - Rimantas Balsys. Lietuvių ir prūsų dievai, deivès, dvasios: nuo apeigos iki prietaro. Klaipeda: Klaipèdos universiteto leidykla.

Blockytè-Naujokè 2020 - Kristina Blockytè-Naujokè. Easter Egg Symbolism in Lithuania Minor. Acta humanitarica universitatis Saulensis. Mokslo darbai. Regionas: istorija, kultūra, kalba, 27. p. 225-241 [Sud. Regina Kvašyte. Šiauliai: Šiaulių universitetas, 2020].

BRMŠ - Baltų religijos ir mitologijos šaltiniai. Sud. N. Vẻlius. Vilnius: Mokslo ir enciklopedijų leidykla, t. I-IV, 1996, 2001, 2003, 2005.

Brazytė-Bindokienė 1989 - Danutė Brazytė-Bindokienè. Lietuviu papročiai ir tradicijos. Čikaga: Pasaulio lietuvių bendruomenè.

Buračas 1993 - Balys Buračas. Lietuvos kaimo papročiai. Vilnius: Mintis.

Čepienė 2002 - Irena Čepienè. Šeimos tradicijos Kintų apylinkèse XX a. pirmojoje puseje. Liaudies kūryba, 86.

Čepienė 2008 - Irena Čepienė Lietuviu etniné kultūra: raidos ịžvalgos. Vilnius: Alma littera.

Daugirdaite 2001 - Vilma Daugirdaitė. Lietuviu lalavimo dainos: lyginamasis tyrimas latviu, baltarusiu, lenku apeigu ir tautosakos kontekste. [Daktaro disertacija]. Vilnius: Lietuvių literatūros ir tautosakos institutas.

Dundulienè 1991 - Pranė Dundulienè. Lietuviu šventès: tradicijos, papročiai, apeigos. Vilnius: Mintis. 
Dundulienė 2008 - Pranė Dundulienè. Lietuvių šventès: tradicijos, papročiai, apeigos. Vilnius: Mokslo ir enciklopedijų leidybos institutas.

Gaerte 1956 - Wilhelm Gaerte. Volksglaube und Brauchtum Ostpreussens. Würsburg: Holzner.

Juška ir kt., 1994 - Albertas Juška ir kt. Lietuvininku žemė. Vilnius: Šviesa.

Kapeleris 1970 - Karlas Kapeleris (Carl Cappeller). Kaip senieji lietuvininkai gyveno. Lietuvininkai: apie Vakarų Lietuva ir jos gyventojus devynioliktajame amžiuje. Paruošè Vacys Milius. Vilnius: Vaga.

Kiseliūnaitė 1992 - Dalia Kiseliūnaitė. Senųjų baltiškųjų papročių pėdsakai lietuvininkų šventėse. Lietuvininku kalba: Mažosios Lietuvos tautosaka: Mažosios Lietuvos etnografija: moksliniu konferenciju pranešimai. Kaunas: Kelias (evangelikų liuteronų Bažnyčios Konsistorijos Komunikacijos ir leidybos centras).

Klimka 2009 - Libertas Klimka. Tradiciniu kalendoriniu švenčiu semantika. Vilnius: VPU leidykla. Lepneris 2011 - Teodoras Lepneris. Prūsų lietuvis. Parengè V. Gerulaitienė. Vilnius: LII leidykla.

Lietuvos kultūra 2012 - Lietuvos kultūra. Mažosios Lietuvos ir Žemaitijos papročiai. Sudarè Ž. Šaknys. Vilnius: Lietuvos istorijos instituto leidykla.

LŽ 1995 - Lietuvininku žodis. Kaunas: Litterae universitatis.

LK 1995 - Lietuvininkų kraštas. Kaunas: Litterae universitatis.

Marcinkevičienė ir kt. 2006 - parengė Nijolè Marcinkevičienė ir kt. Velyku ryta lelija pražydo. Verbu sekmadienio, Velyku, Jurginiu papročiai ir tautosaka. Vilnius: Lietuvių liaudies kultūros centras.

Šaknys 2001 - Žilvytis Šaknys. Kalendoriniai ir darbo papročiai Lietuvoje XIX a. pabaigoje - XX a. pirmojoje pusëje. Jaunimo vakarèliai. Vilnius: „Diemedžio“ leidykla.

Vyšniauskaitė 1993 - Angelè Vyšniauskaitė. Mūsų metai ir šventès. Kaunas: Šviesa.

WDDV 1936 - Wörterbuch der deutschen Volkskunde. Hrsg. von A. Erich, R. Beitl, Leipzig: Alfred Kröner Verlag.

Wrede, 1922 - Adam Wrede. Rheinische Volkskunde. Leipzig: Quelle und Meyer.

\section{Kristina Blockytè-Naujokè}

\section{VELYKOS MAŽOJOJE LIETUVOJE: TRADICIJŲ TĘSTINUMAS IR KAITA}

Santrauka

Straipsnyje, pasitelkiant autentišką lietuvininkų medžiagą, analizuojama Mažosios Lietuvos Velykų specifika chronologiniu aspektu (nuo pirmųjų paminèjimų iki šių dienų), siekiama atskleisti šventès bendruosius raidos etapus ir šiuolaikines papročių transformacijas. Analizuojami pagrindiniai XIX a. pab. - XX a. Velykų modelio elementai, atskleidžiant struktūrinius ir funkcinius kalendorinių apeigų pokyčius. Taip pat siekiama išanalizuoti ir šiuolaikinius (nuo 1990 m.) šventès papročius bei aptarti etninès tradicijos tęstinumo galimybes šių dienų šventès modelyje.

Archajiškajam Velykų šventės modeliui būdingi elementai: kiaušinių dažymas ir įvairūs veiksmai su jais, lalauninkų vaikštynès, supimasis sūpuoklèmis, laistymasis vandeniu ir kitos su vandeniu susijusios apeigos, aukojimas vèlèms. XIX a. pab. - XX a. pr. Mažojoje Lietuvoje galima išskirti kalendorinių papročių apeiginių 
funkcijų nykimo, naujų funkcijų formavimosi bei tradicijų suvienodèjimo procesus. Apeiginès Velykų struktūros užpildomos tais pačiais papročiais kaip ir kitos reikšmingos lietuvininkų kalendoriaus šventès - šventinio laiko akcentavimu, išprovokavusiu vienokị ar kitokị žmogaus elgesị (ịvairūs tikejjimai, draudimai), bendruomeninio pobūdžio apeigomis: šventinị rytą èjimu ị bažnyčią, vienas kito plakimu Velykų pirmąją dieną (kai kur antrąią) beržų / kadagio šakelèmis. XX a. 3-iajame dešimtmetyje ir vèliau pastebima, jog lietuvininkų ritualinè tradicija praranda turètą egzistencinę svarbą, ritualai virsta papročiais, ịgijusiais naujas simbolines reikšmes bei formas. Nebelieka kiaušinio dovanojimo maginès reikšmės, išpopuliarejja velykavimo tradicija bei atsiranda naujas elementas - kiaušinių slëpimas sode padarytuose lizduose vaikams pasakojant, kad juos padejjęs Velykų zuikis.

Šiuolaikiniame lietuvininkų švenčių modelyje bandoma derinti etnines tradicijas su vartotojiškai nusiteikusios šiuolaikinès visuomenės poreikiais. Galima išskirti kelias šventimo formas: šeimos šventę namuose, edukacinius užsiėmimus prieš šventę, Atvelykio šventimą viešoje erdvėje. Nors instituciškai organizuojamos kalendorinès šventės vyksta pagal daugiau ar mažiau visai Lietuvai būdingą scenarijų, tačiau išskiriant tipiškus Mažosios Lietuvos regionui švenčių elementus, centralizuotas kultūros institucijų veiklos organizavimas gali būti palankus puoselèjant vietines lietuvininkų tradicijos formas. 